\title{
Negative regulation of adipose-expressed galectin-12 by isoproterenol, tumor necrosis factor $\alpha$, insulin and dexamethasone
}

\author{
Mathias Fasshauer, Johannes Klein ${ }^{1}$, Ulrike Lossner and Ralf Paschke \\ University of Leipzig, Department of Internal Medicine III, 04103 Leipzig, Germany and ${ }^{1}$ Medical University of Lübeck, Department of Internal Medicine I, \\ 23538 Lübeck, Germany \\ (Correspondence should be addressed to Ralf Paschke,Ph.-Rosenthal-Str.27, 04103 Leipzig, Germany; Email: pasr@medizin.uni-leipzig.de)
}

\begin{abstract}
Objective: Galectin-12 has recently been shown to be a predominantly adipocyte-expressed protein which is stimulated by insulin-sensitizing thiazolidinediones and possesses apoptosis-inducing activity.

Methods: To further clarify galectin-12 regulation and its potential involvement in the development of insulin resistance, 3T3-L1 adipocytes were chronically treated with various hormones known to impair insulin sensitivity, and galectin-12 mRNA was measured by quantitative real-time reverse transcription-polymerase chain reaction.

Results: Treatment of 3T3-L1 cells for $16 \mathrm{~h}$ with $10 \mu \mathrm{mol} / \mathrm{l}$ isoproterenol, $100 \mathrm{nmol} / \mathrm{l}$ insulin, $0.6 \mathrm{nmol} / \mathrm{l}$ tumor necrosis factor $\alpha(\mathrm{TNF} \alpha)$, and $100 \mathrm{nmol} / \mathrm{l}$ dexamethasone reduced galectin-12 gene expression between $47 \%$ and $85 \%$. These negative effects were dose-dependent with significant inhibition detectable at concentrations as low as $10 \mathrm{nmol} / \mathrm{l}$ isoproterenol, $0.06 \mathrm{nmol} / \mathrm{l} \mathrm{TNF} \alpha$, and $1 \mathrm{nmol} / \mathrm{l}$ dexamethasone. Furthermore, the inhibitory effect of isoproterenol could be almost completely reversed by pretreatment with the $\beta$-adrenergic antagonist propranolol and mimicked by stimulation of $\mathrm{G}_{\mathrm{S}}$-proteins with cholera toxin or by activation of adenylyl cyclase with forskolin and dibutyryl-cAMP.

Conclusions: Our results suggest that galectin-12 is an adipocyte-expressed protein which is downregulated by various insulin resistance-inducing hormones. These findings imply a role for galectin12 in the pathogenesis of insulin resistance.
\end{abstract}

European Journal of Endocrinology 147 553-559

\section{Introduction}

Type 2 diabetes affects about 150 million people worldwide and is characterized by insulin resistance of peripheral tissues such as liver, muscle and fat which cannot be overcome by hypersecretion of pancreatic $\beta$-cells (1). Insulin resistance is often associated with obesity, and various studies suggest that several adipose-expressed proteins such as tumor necrosis factor $\alpha(\mathrm{TNF} \alpha)$, resistin, and adiponectin are dysregulated in obesity leading to impaired insulin sensitivity (2). Thiazolidinediones (TZDs) are a new class of antidiabetic drugs that activate peroxisome proliferator-activated receptor (PPAR) gamma and decrease insulin resistance in target tissues (3). Several studies have shown that various candidate proteins in fat are regulated by TZDs and might mediate some of their positive effects on insulin sensitivity. Thus, Steppan et al. suggested resistin as a major target of TZD action (4). However, results have been controversial (5). Another interesting candidate gene is adiponectin which is upregulated by TZDs and improves insulin sensitivity in vitro and in vivo $(6,7)$. Most recently, Hotta et al. suggested galectin-12 as a novel adipose-expressed protein which is upregulated by TZDs (8). Interestingly, the authors demonstrated convincingly that the protein is a potent inductor of apoptosis (8). Based on their findings, they suggested galectin-12 as a TZD-responsive gene which might improve insulin sensitivity at least partly via induction of apoptosis of preferentially large insulin-resistant adipocytes (8). A PPAR element has not, so far, been described in the galectin-12 gene promoter (8).

However, potential regulation of galectin-12 gene expression by other agents modifying insulin resistance is unknown. In the current study, we therefore examined the effect of isoproterenol, insulin, TNF $\alpha$, dexamethasone, angiotensin 2 (AT2), growth hormone $(\mathrm{GH})$, and tri-iodothyronine $\left(\mathrm{T}_{3}\right)$ on galectin-12 gene expression in 3T3-L1 adipocytes in vitro. We demon- 
strate for the first time that isoproterenol, insulin, $\mathrm{TNF} \alpha$, and dexamethasone potently inhibit galectin12 mRNA expression in 3T3-L1 cells whereas AT2, $\mathrm{GH}$, and $\mathrm{T}_{3}$ do not have any effect. Furthermore, we present evidence that the inhibitory effect of isoproterenol is mediated via $\beta$-adrenergic receptors, $G_{S}$-proteins and adenylyl cyclase.

\section{Materials and methods}

\section{Materials}

Cell culture reagents were purchased from Life Technologies, Inc. (Grand Island, NY, USA), and oligonucleotides were purchased from MWG-Biotech (Ebersberg, Germany). All other reagents were obtained from Sigma Chemical Co. (St Louis, MO, USA).

\section{Culture and differentiation of 3T3-L1 cells}

3T3-L1 adipocytes (American Type Culture Collection, Rockville, MD, USA) were cultured as described previously (9). Briefly, preadipocytes were cultured to confluence in DMEM containing $25 \mathrm{mmol} / \mathrm{l}$ glucose, $10 \%$ fetal bovine serum, and antibiotics (culture medium). At confluence, 3T3-L1 cells were cultured for three days in culture medium further supplemented with $1 \mu \mathrm{mol} / \mathrm{l}$ insulin, $0.5 \mathrm{mmol} / \mathrm{l}$ isobutylmethylxanthine and $0.1 \mu \mathrm{mol} / \mathrm{l}$ dexamethasone, and for another three days in culture medium with $1 \mu \mathrm{mol} / \mathrm{l}$ insulin followed by an additional three to six days in culture medium. For experiments, adipocytes were used between days 9 and 12 after induction of differentiation. At this point, at least $90 \%$ of 3T3-L1 cells showed accumulation of fat droplets.

\section{Analysis of galectin-12 gene expression}

Expression of galectin-12 was measured by quantitative real-time RT-PCR in a fluorescent temperature cycler (LightCycler, Roche Molecular Biochemicals, Mannheim, Germany) as described previously (10). Briefly, RNA was isolated from 3T3-L1 adipocytes using TRIzol (Life Technologies, Inc.). One microgram total RNA was reverse transcribed using standard reagents (Life Technologies, Inc.) and one tenth of each RT reaction was amplified in a $20 \mu \mathrm{l} \mathrm{PCR} \mathrm{containing} 3 \mathrm{mmol} / \mathrm{l}$ $\mathrm{MgCl}_{2}, 0.5 \mu \mathrm{mol} / \mathrm{l}$ of each primer and $1 \times$ LightCycler DNA Master SYBR Green I mix (Roche Molecular Biochemicals). After an initial denaturation at $94^{\circ} \mathrm{C}$ for $30 \mathrm{~s}, 40$ PCR cycles were performed, each cycle consisting of $94^{\circ} \mathrm{C}$ for $1 \mathrm{~s}, 61^{\circ} \mathrm{C}$ for $7 \mathrm{~s}$, and $72{ }^{\circ} \mathrm{C}$ for $11 \mathrm{~s}$. The following primer pairs were used: galectin-12 (accession no. AF244978) CTCCGCCCCCTTCCTCTTTCACC (sense) and GCCCTTGGAGCCCTTCTTAGCAGT (antisense); 36B4 (accession no. NM007475) AAGCGCGTCCTGGCATTGTCT (sense) and CCGCAGGGGCAGCAGTGGT (antisense). After each cycle SYBR Green I fluorescence emissions were monitored. Levels of galectin-12 and 36B4 mRNA were quantified by using the second derivative maximum method of the LightCycler Software (Roche Molecular Biochemicals) which determines the crossing points of individual samples by an algorithm identifying the first turning point of the fluorescence curve. Galectin-12 expression is given relative to $36 \mathrm{~B} 4$ which has been frequently used as an internal control due to its resistance to hormonal regulation (11).

Amplification of specific transcripts was confirmed by performing melting curve profiles (cooling the sample to $68^{\circ} \mathrm{C}$ and heating slowly to $95^{\circ} \mathrm{C}$ with continuous measurement of fluorescence) at the end of each PCR. Furthermore, the specificity was verified by subjecting the PCR products to agarose gel electrophoresis.

\section{Statistical analysis}

Results are shown as means \pm S.E.M. Differences between various treatments were tested with unpaired Student's t-tests. $P$ values $<0.01$ are considered highly significant.

\section{Results}

\section{Galectin-12 mRNA expression is stimulated during differentiation}

First, expression of galectin-12 mRNA during differentiation was determined. Galectin-12 synthesis dramatically increased over the course of differentiation and was about 1000-fold higher on day 9 of differentiation as compared with confluent 3T3-L1 preadipocytes on day $0(P<0.01)$ (Fig. 1).

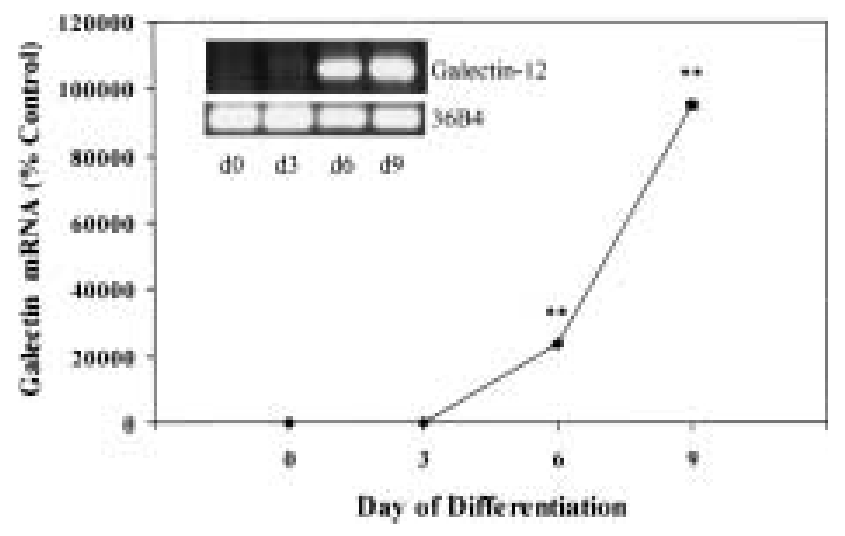

Figure 1 Differentiation-dependent galectin-12 gene expression. Confluent preadipocytes (day 0) were differentiated and at the indicated days of differentiation total RNA was subjected to quantitative real-time RT-PCR. Galectin-12 mRNA levels are shown relative to cells on day $0(=100 \%)$. Results are the means \pm S.E.M. of two independent experiments. ${ }^{* \star} P<0.01$, comparing confluent cells (day 0) with differentiated adipocytes (day 6 and 9). Inset: agarose gel electrophoresis of the PCR products for galectin-12 and 36B4 respectively at cycle 30 . d, day. 


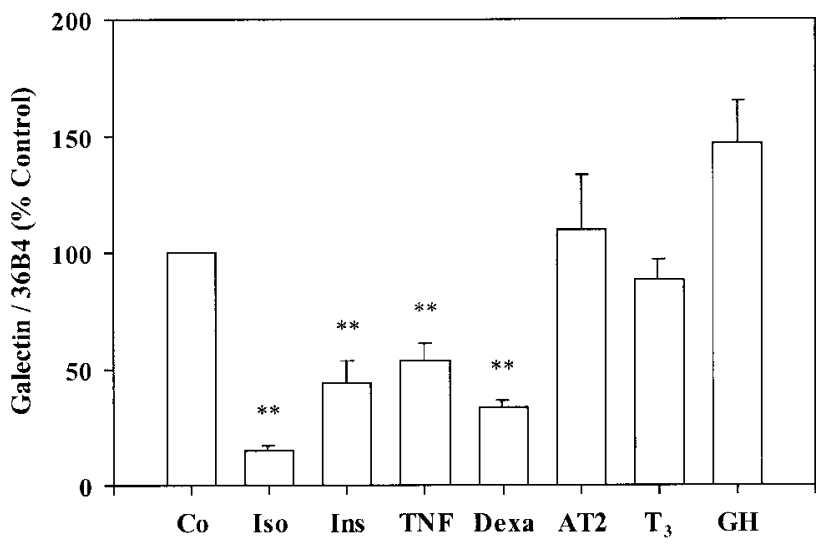

Figure 2 Galectin-12 gene expression is inhibited by isoproterenol, insulin, TNF $\alpha$, and dexamethasone. After $6 \mathrm{~h}$ serum deprivation, fully differentiated 3T3-L1 adipocytes were stimulated for $16 \mathrm{~h}$ with isoproterenol (Iso, $10 \mu \mathrm{mol} / \mathrm{I})$, insulin (Ins, $100 \mathrm{nmol} / \mathrm{l}$ ), $\mathrm{TNF}_{\alpha}(\mathrm{TNF}, 0.6 \mathrm{nmol} / \mathrm{l})$, dexamethasone (Dexa, $\left.100 \mathrm{nmol} / \mathrm{l}\right)$, AT2 $(10 \mu \mathrm{mol} / \mathrm{l}), \mathrm{T}_{3}(1 \mu \mathrm{mol} / \mathrm{l})$, and $\mathrm{GH}(23 \mathrm{nmol} / \mathrm{l})$. Total RNA was subjected to quantitative real-time RT-PCR to determine galectin-12 mRNA levels normalized to 36B4 as described in Materials and methods. Expression is shown relative to untreated control (Co) cells $(=100 \%)$. Results are the means \pm S.E.M. of at least four independent experiments. ${ }^{\star \star} P<0.01$, comparing hormone-treated with non-treated cells.

\section{Isoproterenol, insulin, TNF $\alpha$, and dexamethasone inhibit galectin-12 expression}

As galectin-12 has recently been shown to be induced by insulin-sensitizing TZDs, we tested whether various hormones that induce insulin resistance might influence galectin-12 gene expression in 3T3-L1 adipocytes in vitro. Interestingly, treatment of 3T3-L1 cells with $10 \mu \mathrm{mol} / \mathrm{l}$ isoproterenol, $100 \mathrm{nmol} / \mathrm{l}$ insulin, $0.6 \mathrm{nmol} / \mathrm{l} \mathrm{TNF} \alpha$, and $100 \mathrm{nmol} / \mathrm{l}$ dexamethasone for $16 \mathrm{~h}$ decreased galectin-12 mRNA expression by $85 \%$, $55 \%, 47 \%$, and $67 \%$ respectively, as compared with untreated controls $(P<0.01)$ (Fig. 2). In contrast, AT $2(10 \mu \mathrm{mol} / \mathrm{l}), \mathrm{T}_{3}(1 \mu \mathrm{mol} / \mathrm{l})$ and $\mathrm{GH}(23 \mathrm{nmol} / \mathrm{l})$ did not significantly influence expression of galectin12 (Fig. 2).

Isoproterenol, $\mathrm{TNF} \alpha$, and dexamethasone inhibited galectin-12 mRNA synthesis in a dose-dependent fashion. Thus, a significant $42 \%$ reduction of galectin12 mRNA expression was detectable at isoproterenol concentrations as low as $10 \mathrm{nmol} / \mathrm{l}(P<0.01)$ (Fig. $3 \mathrm{~A})$. Moreover, significant $31 \%$ and $43 \%$ inhibition was detectable at $0.06 \mathrm{nmol} / \mathrm{l} \mathrm{TNF} \alpha$ (Fig. 3B) and $1 \mathrm{nmol} / \mathrm{l}$ dexamethasone respectively (Fig. 3C) $(P<$ $0.01)$.

\section{Inhibition of galectin-12 expression by isoproterenol is mediated via $\beta$-adrenergic receptors, $G_{S}$-proteins, and adenylyl cyclase}

To verify that isoproterenol inhibits galectin-12 expression via $\beta$-adrenergic receptors, 3T3-L1 adipo- cytes were pretreated with selective $\alpha$ - (phentolamine, $100 \mu \mathrm{mol} / \mathrm{l}$ ) and $\beta$ - (propranolol, $100 \mu \mathrm{mol} / \mathrm{l}$ ) adrenergic antagonists for $1 \mathrm{~h}$ before isoproterenol $(10 \mu \mathrm{mol} / \mathrm{l})$ was added for $16 \mathrm{~h}$. Again, galectin-12 mRNA expression significantly decreased by $89 \%$ after addition of isoproterenol as compared with untreated control cells $(P<0.01)$ (Fig. 4). Propranolol reversed this inhibitory effect of isoproterenol on galectin-12 gene expression to $75 \%$ of the levels observed in control cells $(P<0.01)$ whereas phentolamine did not have any effect (Fig. 4). These results suggest that the reduction of galectin-12 mRNA expression by isoproterenol is mediated via $\beta$-adrenergic receptors.

As $\beta$-adrenergic receptors are typically coupled to $\mathrm{G}_{\mathrm{S}^{-}}$ proteins mediating the stimulation of adenylyl cyclase, the effects of cholera toxin, forskolin and dibutyrylcAMP on galectin-12 gene expression were examined. Cholera toxin activates $\mathrm{G}_{\mathrm{S}}$-proteins by ADP-ribosylation, forskolin is a direct activator of adenylyl cyclase, whereas dibutyryl-cAMP is a stable cAMP analog. As shown in Fig. 5 all three effectors significantly inhibited galectin-12 gene expression between $89 \%$ and 97\%. These effects were dose-dependent with significant inhibition detectable at concentrations as low as $0.12 \mathrm{nmol} / \mathrm{l}$ cholera toxin, $2 \mu \mathrm{mol} / \mathrm{l}$ forskolin, and $10 \mathrm{mmol} / \mathrm{l}$ dibutyryl cAMP respectively (data not shown).

\section{Inhibition of galectin-12 expression by TNF $\alpha$ is not reversed by inhibition of $p 44 / 42 \mathrm{MAP}$ kinase, p38 MAP kinase, phosphatidylinositol (PI) 3-kinase, and protein kinase C (PKC)}

P44/42 and p38 MAP kinase, as well as PI 3-kinase and $\mathrm{PKC}$ have been implicated in $\mathrm{TNF} \alpha$ signaling (12). To examine a potential involvement of these proteins in $\mathrm{TNF} \alpha$-mediated downregulation of galectin-12, 3T3-L1 adipocytes were pretreated with specific pharmacological inhibitors before addition of TNF $\alpha$. As shown in Fig. 6, inhibition of p44/42 MAP kinase, p38 MAP kinase, PI 3-kinase and PKC by PD98059, SB203580, LY294002 and GF109203X respectively, did not reverse but rather tended to augment inhibition of galectin-12 mRNA expression by TNF $\alpha$.

\section{Inhibition of galectin-12 expression by insulin is not mediated via p44/42 MAP kinase, PI 3-kinase, and p70S6 kinase}

The effect of inhibition of p44/42 MAP kinase, PI 3kinase and p70S6 kinase by PD98059, LY294002 and rapamycin respectively, on insulin-mediated suppression of galectin-12 expression was assessed. Interestingly, pretreatment with the three inhibitors did not significantly alter the insulin-induced decrease of galectin-12 mRNA (Fig. 6). 
A

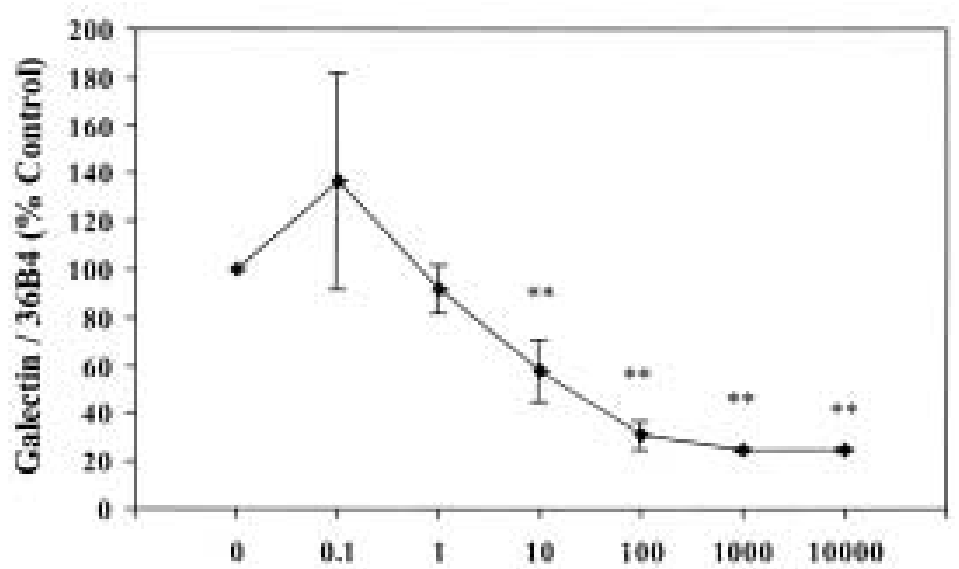

B

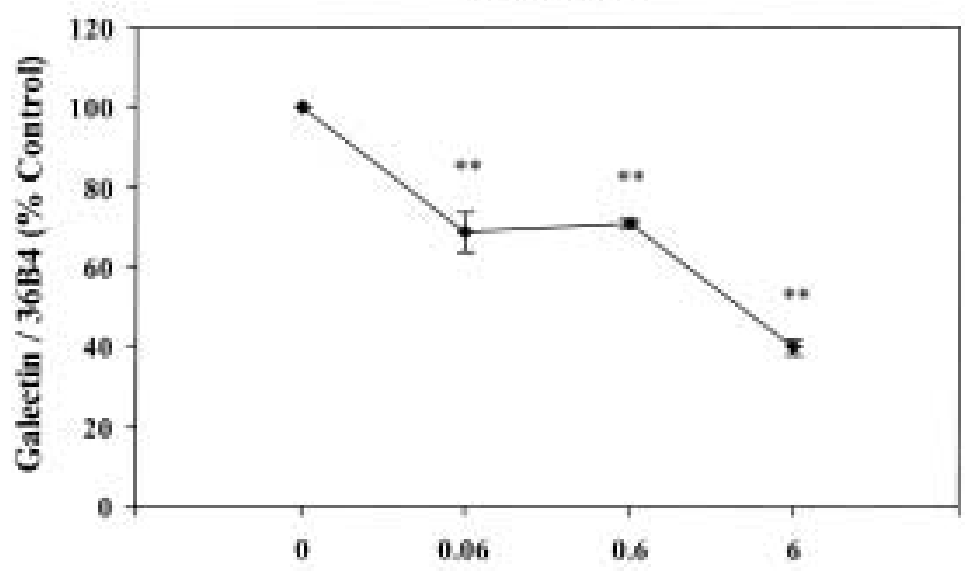

C

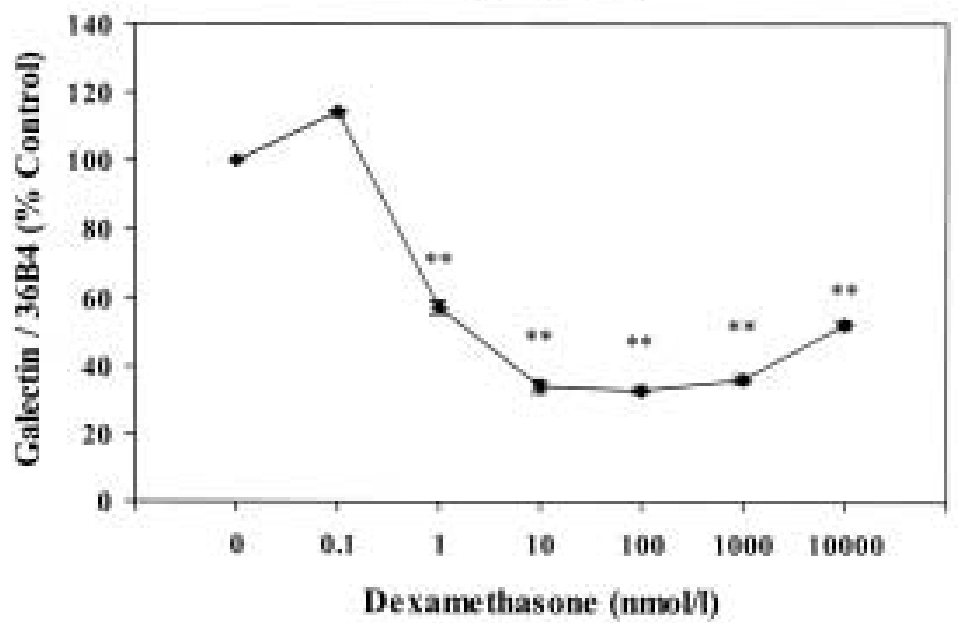

Figure 3 Dose-dependent inhibition of galectin-12 gene expression by isoproterenol, TNF $\alpha$, and dexamethasone. 3T3-L1 cells were serum-starved for $6 \mathrm{~h}$ before the indicated concentrations of isoproterenol (Iso, A), TNF $\alpha$ (TNF, B), and dexamethasone (C) were added for $16 \mathrm{~h}$. After extraction, total RNA was subjected to quantitative real-time RT-PCR to determine galectin-12 mRNA levels normalized to 36B4 as described in Materials and methods. Data are expressed relative to untreated control cells $(=100 \%)$. Results are the means \pm S.E.M. of at least two independent experiments. ${ }^{\star \star} P<0.01$, comparing effector-treated with non-treated cells.

\section{Discussion}

In this study, we demonstrate a potent negative regulation of galectin-12 by insulin resistance-inducing hormones. Until now, 12 members of the galectin family have been isolated from various tissues. All members share a highly conserved carbohydrate-recognition domain which recognizes the carbohydrate moieties of cell surface proteins (13). Galectins have been shown to contribute to cell adhesion, migration, and growth regulation (14). Furthermore, several members induce cellular apoptosis including galectin-12 which 


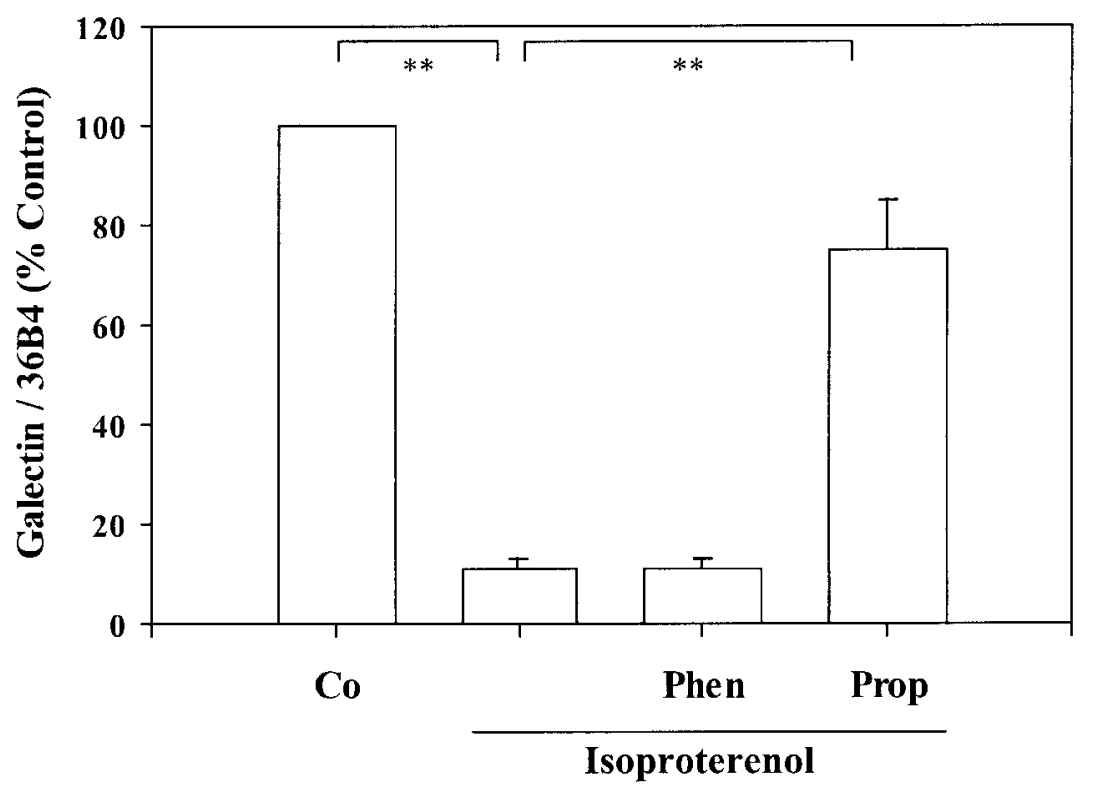

Figure 4 Negative regulation of galectin-12 gene expression by isoproterenol is mediated via $\beta$-adrenergic receptors. After serum starvation for $5 \mathrm{~h}$, adipocytes were cultured in the presence or absence of phentolamine (Phen, $100 \mu \mathrm{mol} / \mathrm{l}$ ) or propranolol (Prop, $100 \mu \mathrm{mol} / \mathrm{l})$ for $1 \mathrm{~h}$ before isoproterenol $(10 \mu \mathrm{mol} / \mathrm{l})$ was added for $16 \mathrm{~h}$. Total RNA was extracted and subjected to quantitative real-time RT-PCR as described in Materials and methods. Galectin-12 mRNA levels normalized to 36B4 expression are shown relative to non-treated control $(\mathrm{Co})$ cells $(=100 \%)$. Results are the means \pm S.E.M. of four independent experiments. ${ }^{* \star} P<0.01$, comparing isoproterenoltreated with non-treated and propranolol-pretreated adipocytes. was cloned as a galectin preferentially expressed in fat tissue (8). Synthesis of galectin-12 increased in adipose tissue after treatment with troglitazone and significantly correlated with the percentage of apoptotic nuclei in fat (8). Interestingly, induction of apoptosis of preferentially large adipocytes has been suggested as one mechanism by which TZDs increase insulin sensitivity (15). Based on these findings it was suggested that galectin-12 mediates some of the insulin-sensitizing effects of TZDs via induction of apoptosis in fat cells. Moreover, it is possible that various insulin resistance-inducing hormones influence insulin sensitivity at least partly via downregulation of galectin-12. To test this hypothesis, 3T3-L1 adipocytes were used as an in vitro model as they show high expression of galectin-12 and are responsive to treatment by various hormones $(8,16)$.

There is growing evidence that increased activity of the sympathetic nervous system contributes to insulin resistance and that catecholamines impair insulin sensitivity $(17-21)$. In a clinical context, our group recently demonstrated that patients with pheochromocytoma are insulin-resistant due to increased serum levels of catecholamines (22). Moreover, insulin sensitivity could be improved by surgical removal of the tumors in most cases (22). The mechanisms by which $\beta$-adrenergic activation impairs insulin sensitivity are not completely understood. In the present study, we demonstrate for the first time that isoproterenol decreases galectin-12 gene expression in 3T3-L1

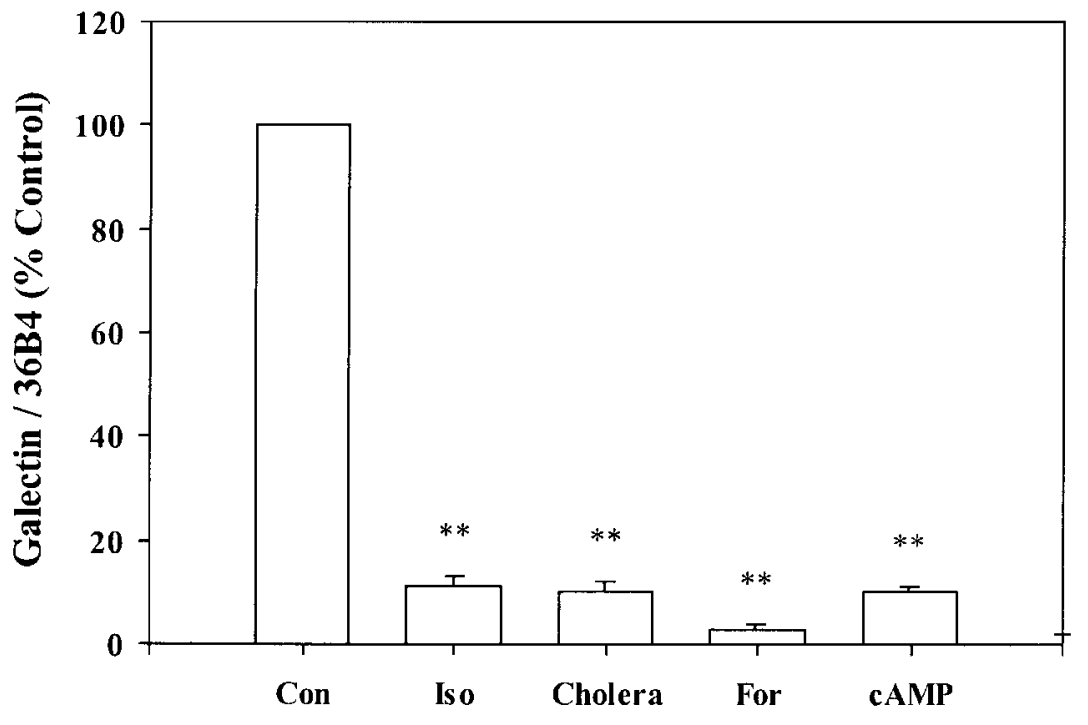

Figure 5 Inhibition of galectin-12 gene expression by isoproterenol is mediated via $\mathrm{G}_{\mathrm{S}}$-proteins and adenylyl cyclase. After 3T3L1 adipocytes were serum-starved for $6 \mathrm{~h}$, isoproterenol (Iso, $10 \mu \mathrm{mol} / \mathrm{l})$, cholera toxin (Cholera, $12 \mathrm{nmol} / \mathrm{I})$, forskolin (For, $200 \mu \mathrm{mol} / \mathrm{l})$, and dibutyryl-cAMP (cAMP, $100 \mathrm{mmol} / \mathrm{l})$ were added for $16 \mathrm{~h}$. Total RNA was extracted and quantitative real-time RTPCR determining galectin-12 mRNA levels normalized to 36B4 was performed as described in Materials and methods. Data are expressed relative to non-treated control (Con) cells $(=100 \%)$. Results are the means \pm S.E.M. of four independent experiments. ${ }^{* *} P<0.01$, comparing non-treated with isoproterenol-, cholera toxin-, forskolin-, and dibutyryl-cAMP-treated cells. 


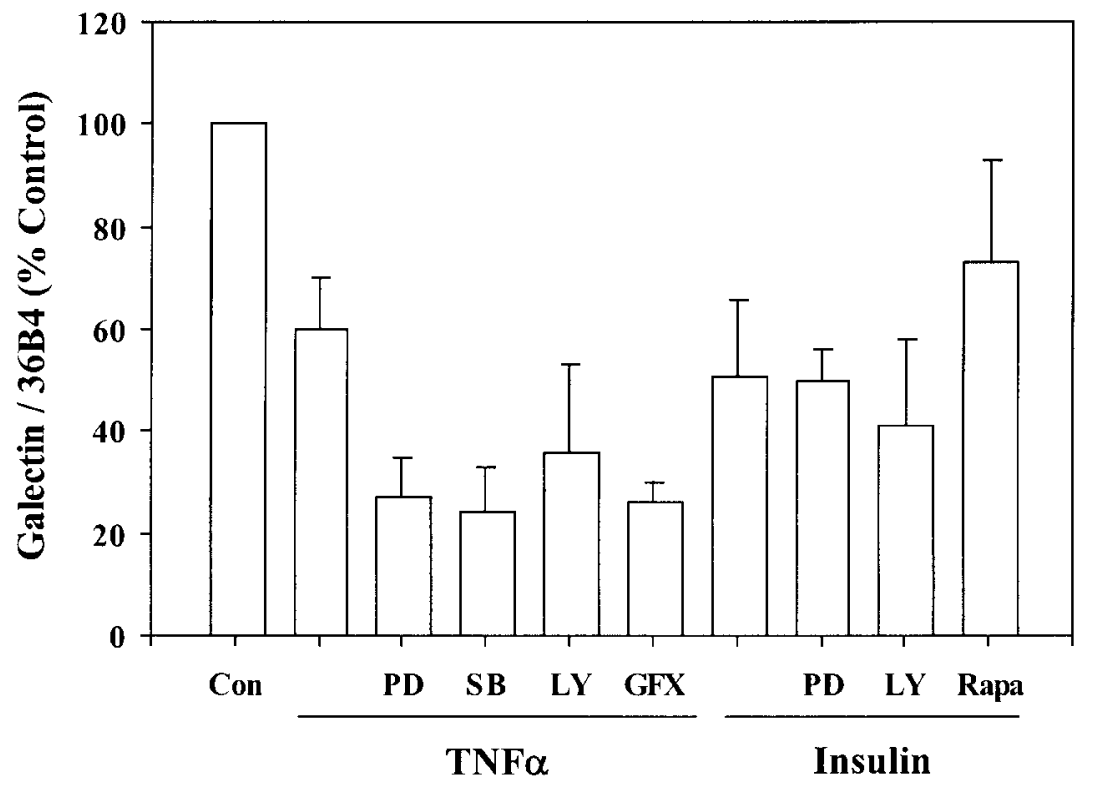

Figure 6 Suppression of galectin-12 mRNA by TNF $\alpha$ is not mediated via p44/42 MAP kinase, p38 MAP kinase, PI 3-kinase, and PKC, and suppression by insulin is not mediated via p44/42 MAP kinase, PI 3kinase, and p70S6 kinase. After serum-starvation for $5 \mathrm{~h}, 3 \mathrm{~T} 3-\mathrm{L} 1$ adipocytes were pretreated in the presence or absence of PD98059 (PD, $50 \mu \mathrm{mol} / \mathrm{l})$, SB203580 (SB, $20 \mu \mathrm{mol} / \mathrm{I}), \mathrm{LY} 294002$ (LY, $10 \mu \mathrm{mol} / \mathrm{l})$, GF109203X (GFX, $10 \mu \mathrm{mol} / \mathrm{l})$, and rapamycin (Rapa, $1 \mu \mathrm{mol} / \mathrm{l}$ ) before addition of TNF $\alpha$ $(0.6 \mathrm{nmol} / \mathrm{l})$ or insulin $(100 \mathrm{nmol} / \mathrm{l})$ for $16 \mathrm{~h}$ as indicated. After total RNA extraction, quantitative real-time RT-PCR determining galectin12 mRNA levels normalized to 36B4 was performed as described in Materials and methods. Data are expressed relative to nontreated control (Con) cells ( $=100 \%)$. Results are the means \pm S.E.M. of two to six independent experiments. adipocytes which might contribute to insulin resistance induced by catecholamines. Thus, based on the original findings (8), it appears possible that downregulation of galectin-12 impairs reduction of large insulin-resistant fat cells via apoptosis which, in turn, contributes to insulin resistance. However, as 3T3-L1 adipocytes show low basal levels of apoptosis $(23,24)$, the influence of various hormones on apoptotic rate was not directly assessed in the current study. Furthermore, we demonstrate for the first time that insulin, $\mathrm{TNF} \alpha$, and dexamethasone are potent inhibitors of galectin12 gene expression. These data suggest that suppression of galectin-12 may be a novel mechanism by which hyperinsulinemia, $\mathrm{TNF} \alpha$, and glucocorticoids impair glucose tolerance and lend support to the hypothesis that this could represent a general biological mechanism for the induction of insulin resistance. In concert with previously demonstrated mechanisms such as downregulation of insulin signaling molecules (1), molecular interactions between adrenergic and insulin signaling cascades $(25,26)$, as well as regulation of other adipocytokines such as adiponectin (27), galectin-12 may be another intriguing player in the complex pathophysiological scenario causing the insulin resistance syndrome.

Furthermore, we show evidence that isoproterenol inhibits galectin-12 gene expression via activation of $\mathrm{G}_{\mathrm{S}}$-proteins and adenylyl cyclase. These results are in accordance with the classical view of $\beta$-adrenergic receptors being coupled to protein kinase $A$ via $G_{S}$-proteins (28). Finally, we demonstrate that inhibition of various well-defined $\mathrm{TNF} \alpha$ and insulin signaling molecules such as p44/42 MAP kinase and PI 3-kinase does not reverse suppression of galectin-12 mRNA induced by either hormone. Thus, further studies are needed to clarify which alternative pathways mediate the inhibitory effect of both insulin and $\mathrm{TNF} \alpha$.

Increased serum levels of thyroid hormones, AT2 or $\mathrm{GH}$ have also been shown to impair glucose tolerance profoundly (29-31). In our in vitro system, none of these hormones affect galectin-12 gene expression. Therefore, our data do not suggest a major role for galectin-12 in insulin resistance induced by these hormones.

In summary, we demonstrate for the first time that isoproterenol, insulin, $\mathrm{TNF} \alpha$, and glucocorticoids significantly inhibit galectin-12 expression in 3T3-L1 cells in vitro. As galectin-12 is a TZD-responsive factor that induces apoptosis, regulation of this protein may constitute an important element in the pathogenesis of insulin resistance and the insulin resistance syndrome.

\section{Acknowledgements}

This work was supported by a grant of the FORMEL1 program of the University of Leipzig (to M F).

\section{References}

1 Matthaei S, Stumvoll M, Kellerer M \& Haring HU. Pathophysiology and pharmacological treatment of insulin resistance. Endocrine Review 200021 585-618.

2 Spiegelman BM \& Flier JS. Obesity and the regulation of energy balance. Cell $2001 \mathbf{1 0 4} 531-543$.

3 Stumvoll M \& Haring H. Insulin resistance and insulin sensitizers. Hormone Research 200155 3-13.

4 Steppan CM, Bailey ST, Bhat S, Brown EJ, Banerjee RR, Wright $\mathrm{CM}$ et al. The hormone resistin links obesity to diabetes. Nature 2001409 307-312.

5 Way JM, Gorgun CZ, Tong Q, Uysal KT, Brown KK, Harrington WW et al. Adipose tissue resistin expression is severely suppressed 
in obesity and stimulated by peroxisome proliferator-activated receptor gamma agonists. Journal of Biological Chemistry 2001 $27625651-25653$.

6 Yamauchi T, Kamon J, Waki H, Terauchi Y, Kubota N, Hara K et al. The fat-derived hormone adiponectin reverses insulin resistance associated with both lipoatrophy and obesity. Nature Medicine $20017941-946$.

7 Berg AH, Combs TP, Du X, Brownlee M \& Scherer PE. The adipocytesecreted protein Acrp30 enhances hepatic insulin action. Nature Medicine 20017 947-953.

8 Hotta K, Funahashi T, Matsukawa Y, Takahashi M, Nishizawa H, Kishida K et al. Galectin-12, an adipose-expressed galectin-like molecule possessing apoptosis-inducing activity. Journal of Biological Chemistry 2001276 34089-34097.

9 Fasshauer M, Klein J, Neumann S, Eszlinger M \& Paschke R. Isoproterenol inhibits resistin gene expression through a $\mathrm{G}(\mathrm{S})$-protein-coupled pathway in 3T3-L1 adipocytes. FEBS Letters 2001 500 60-63.

10 Fasshauer M, Klein J, Neumann S, Eszlinger M \& Paschke R. Tumor necrosis factor alpha is a negative regulator of resistin gene expression and secretion in 3T3-L1 adipocytes. Biochemical and Biophysical Research Communications 2001288 1027-1031.

11 Lin J, Puigserver P, Donovan J, Tarr P \& Spiegelman BM. Peroxisome proliferator-activated receptor gamma coactivator 1 beta (PGC-1beta), a novel PGC-1-related transcription coactivator associated with host cell factor. Journal of Biological Chemistry 2002277 1645-1648.

12 Liu ZG \& Han J. Cellular responses to tumor necrosis factor. Current Issues in Molecular Biology 20013 79-90.

13 Barondes SH, Castronovo V, Cooper DN, Cummings RD, Drickamer K, Feizi T et al. Galectins: a family of animal beta-galactosidebinding lectins. Cell 199476 597-598.

14 Barondes SH, Cooper DN, Gitt MA \& Leffler H. Galectins. Structure and function of a large family of animal lectins. Journal of Biological Chemistry $199426920807-20810$.

15 Okuno A, Tamemoto H, Tobe K, Ueki K, Mori Y, Iwamoto K et al. Troglitazone increases the number of small adipocytes without the change of white adipose tissue mass in obese Zucker rats. Journal of Clinical Investigation 1998101 1354-1361.

16 Fasshauer M, Klein J, Neumann S, Eszlinger M \& Paschke R. Hormonal regulation of adiponectin gene expression in 3T3-L1 adipocytes. Biochemical and Biophysical Research Communications $20022901084-1089$.

17 Landsberg L. Role of the sympathetic adrenal system in the pathogenesis of the insulin resistance syndrome. Annals of the New York Academy of Sciences $1999 \mathbf{8 9 2} 84-90$.

18 Reaven GM, Lithell H \& Landsberg L. Hypertension and associated metabolic abnormalities - the role of insulin resistance and the sympathoadrenal system. New England Journal of Medicine 1996 $334374-381$.

19 Hoieggen A, Fossum E, Nesbitt SD, Palmieri V \& Kjeldsen SE. Blood viscosity, plasma adrenaline and fasting insulin in hypertensive patients with left ventricular hypertrophy. ICARUS, a LIFE Substudy. Insulin CARotids US Scandinavica. Blood Pressure 2000 9 83-90.

20 Facchini FS, Stoohs RA \& Reaven GM. Enhanced sympathetic nervous system activity. The linchpin between insulin resistance, hyperinsulinemia, and heart rate. American Journal of Hypertension $199691013-1017$.

21 Maison P, Byrne CD, Hales CN \& Wareham NJ. Hypertension and its treatment influence changes in fasting nonesterified fatty acid concentrations: a link between the sympathetic nervous and the metabolic syndrome? Metabolism 200049 81-87.

22 Bluher M, Windgassen M \& Paschke R. Improvement of insulin sensitivity after adrenalectomy in patients with pheochromocytoma. Diabetes Care 200023 1591-1592.

23 Magun R, Boone DL, Tsang BK \& Sorisky A. The effect of adipocyte differentiation on the capacity of 3T3-L1 cells to undergo apoptosis in response to growth factor deprivation. International Journal of Obesity Related Metabolic Disorders 199822 567-571.

24 Urso B, Niesler CU, O’Rahilly S \& Siddle K. Comparison of antiapoptotic signalling by the insulin receptor and IGF-I receptor in preadipocytes and adipocytes. Cell Signal 200113 279-285.

25 Klein J, Fasshauer M, Ito M, Lowell BB, Benito M \& Kahn CR. Beta(3)-adrenergic stimulation differentially inhibits insulin signaling and decreases insulin-induced glucose uptake in brown adipocytes. Journal of Biological Chemistry 1999274 3479534802.

26 Klein J, Fasshauer M, Benito M \& Kahn CR. Insulin and the beta3adrenoceptor differentially regulate uncoupling protein-1 expression. Molecular Endocrinology 200014 764-773.

27 Fasshauer M, Klein J, Neumann S, Eszlinger M \& Paschke R. Adiponectin gene expression is inhibited by beta-adrenergic stimulation via protein kinase A in 3T3-L1 adipocytes. FEBS Letters 2001507 142-146.

28 Collins S \& Surwit RS. The beta-adrenergic receptors and the control of adipose tissue metabolism and thermogenesis. Recent Progress in Hormone Research 200156 309-328.

29 Fickova M, Zorad S \& Macho L. The effect of in vivo thyroxine treatment on insulin receptors, glucose transport and GLUT4 in rat adipocytes. Hormone Metabolism Research 199729 16-19.

30 Folli F, Saad MJ, Velloso L, Hansen H, Carandente O, Feener EP et al. Crosstalk between insulin and angiotensin II signalling systems. Experimental and Clinical Endocrinology and Diabetes 1999 107 133-139.

31 Takano A, Haruta T, Iwata M, Usui I, Uno T, Kawahara J et al. Growth hormone induces cellular insulin resistance by uncoupling phosphatidylinositol 3-kinase and its downstream signals in 3t3-l1 adipocytes. Diabetes $2001501891-1900$.

Received 27 March 2002

Accepted 25 June 2002 